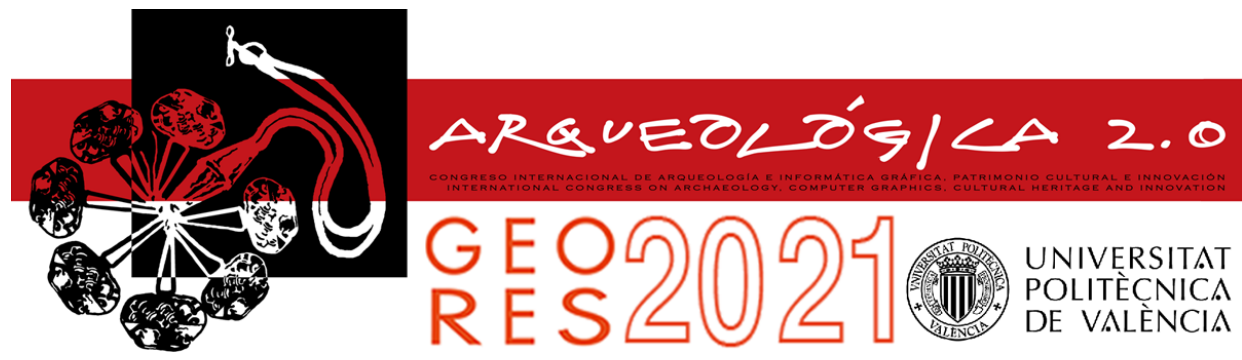

Proceedings of the joint international event $9^{\text {th }}$ ARQUEOLÓGICA

$2.0 \& 3^{\text {rd }}$ GEORES

Valencia (Spain).

26-28 April 2021

\title{
AN INTERACTIVE 3D APPLICATION OF A HOUSE FROM THE XVI CENTURY IN SAN CRISTÓBAL DE LAGUNA AS A CASE STUDY FOR THE DISSEMINATION OF CULTURAL HERITAGE
}

\author{
Isabel Sánchez-Berrie|a, ${ }^{a}$, Alejandro González-Gonzáleza ${ }^{a}$, Fernando Pérez-Navaa ${ }^{a}$ Cecile Meier ${ }^{b}$, \\ Jesús Pérez-Morerac ${ }^{c}$, Carmen Rosa Hernández-Alberto ${ }^{d}$ \\ ${ }^{a}$ Departamento de Ingeniería Informática y Sistemas, Escuela Superior de Ingeniería y Tecnología, Camino San Francisco de Paula \\ s/n, 38200 La Laguna, Spain. isanchez@ull.edu.es; fdoperez@ull.edu.es; esit@ull.edu.es \\ ${ }^{b}$ Departamento de Bellas Artes, Facultad de Bellas Artes, C/ Prof. José Luis Moreno Becerra s/n, 38200 La Laguna, Spain. \\ cemeier@ull.es
}

c Departamento de Historia del Arte y Filosofía, Facultad de Humanidades, C/ Prof. José Luis Moreno Becerra s/n, 38200 La Laguna, Spain.jperezmo@ull.edu.es

${ }^{d}$ Ayuntamiento de San Cristóbal de La Laguna, C/ Obispo Rey Redondo 1, 38201 La Laguna, Spain. rheralb@lalaguna.es

\begin{abstract}
:
At the end of the XVI century, the historic centre of San Cristóbal de La Laguna was definitively configured as we know it today, as can be seen in the first preserved map of the city, drawn in 1588 by the engineer Leonardo Torriani. It is the first non-fortified Spanish colonial city and its plan has provided a model for the colonial cities of America, making it a UNESCO World Heritage site. The dissemination of this legacy is a task of great importance. A tool of increasing importance for the dissemination and preservation of history and cultural heritage are reconstructions and virtual recreations in 3D. This paper presents a case of the use of these tools for the dissemination of the city's heritage. The 3D modelling of one of the most characteristic types of housing in San Cristóbal de La Laguna in the $16^{\text {th }}$ century is carried out along with the 3D modelling of human virtual characters all based on the historical documentation of that time. With these elements, a WebGL application has been implemented in which a user can visit the virtually reconstructed house and receive information on the construction systems and architecture in the city in the XVI century.
\end{abstract}

Keywords: virtual reality (VR), 3D modelling, 3D visualization, virtual characters, cultural heritage

\section{Introduction}

Three-dimensional reconstructions and virtual recreations have become useful tool for the dissemination and preservation of history and cultural heritage. The recent advances and ease of access in multimedia technologies have generated a growing development of attractive experiences for learning (Bostanci, Kanwal \& Clark, 2015). Among these technologies, we highlight Virtual Reality (VR) as a support for the creation of sensory experiences that contribute to a better understanding and dissemination of cultural heritage. VR constitutes one of the most attractive and promising tools in this field since it offers the possibility for users to perceive heritage through their senses and to even manipulate and act on the objects of study (Bekele, Pierdicca, Frontoni, Malinverni, \& Gain, 2018). In this way, a more natural and instinctive way of learning is achieved, compared to symbol-based learning (Carrozzino, Bergamasco, 2010). Besides this, in learning applications, recreations of cultural elements located in spatial locations at determined temporal instants can be provided that would not be possible otherwise (Vincent, Defanti, Schulze, Kuester, \& Levy, 2013).

An increasing number of entities are taking advantage of this technology to illustrate the reconstructions of buildings at different times in the past. These reconstructions include in recent years virtual human characters in VR applications given the degree of maturity of the technology. The characters are mainly used as virtual teachers to obtain a more user-friendly and attractive application. It should be noted that in this type of recreation it is considered that the introduction of characters helps us to contextualize and better understand the reconstruction (Machidon, Duguleană \& Carrozzino, 2018).

In this paper we present an application belonging to a research project that aims to develop an immersive experience of the city of San Cristóbal de La Laguna

‘Corresponding Author: Isabel Sánchez-Berriel, isanchez@ull.edu.es 
(commonly called La Laguna) in the $16^{\text {th }}$ century. This work focuses on the virtual reconstruction of a domestic house in La Laguna from the XVI century. The advantages outlined before on the use of technologies for the dissemination of cultural heritage are used to show the house features and customs of that time. In the application, virtual human characters are introduced and their clothes reproduce those that could be found at that century, creating empathy with the context in which the user is immersed. These characters are part of the virtual recreation and will allow the user to understand the uses and cultural significance of the reconstructed environment. By means of these elements, it is intended that the Virtual Reality application promotes the general interest towards the patrimonial and cultural heritage of the city.

\section{Architecture of San Cristóbal de La Laguna in the XVI century}

\subsection{La Laguna in the XVI century}

In 1496, the island of Tenerife became part of the Crown of Castile, the year in which the city of San Cristóbal de La Laguna was also founded (Abreu, 1977). After the conquest of the island, the distribution of land and repopulation began with new inhabitants from the Kingdom of Castile (from the regions of Andalusia, Extremadura, Galicia ...) and also from Portugal, the Netherlands and Genoa. The first settlement of the city took place in the area where the church of La Concepción stands today (Cioranescu, 1965; Aznar, 2008). The first houses and a small chapel dedicated to the Virgin of La Concepción were built in the so-called Upper Town. Towards 1500 the configuration of the city changed, promoted by the King's delegate: el Adelantado, moving the new buildings to what would be the Lower Town. The Island Government: el Cabildo agreed to draw an expansion plan in a southerly direction, establishing a grid (checkerboard plan) of ordered streets, according to the taste that prevailed in the European Renaissance at that time. In this way, the historical centre of the city was definitely configured as we know it today at the end of the $16^{\text {th }}$ century, as observed in the map drawn in 1588 by the military engineer Leonardo Torriani as shown in Figure 1.

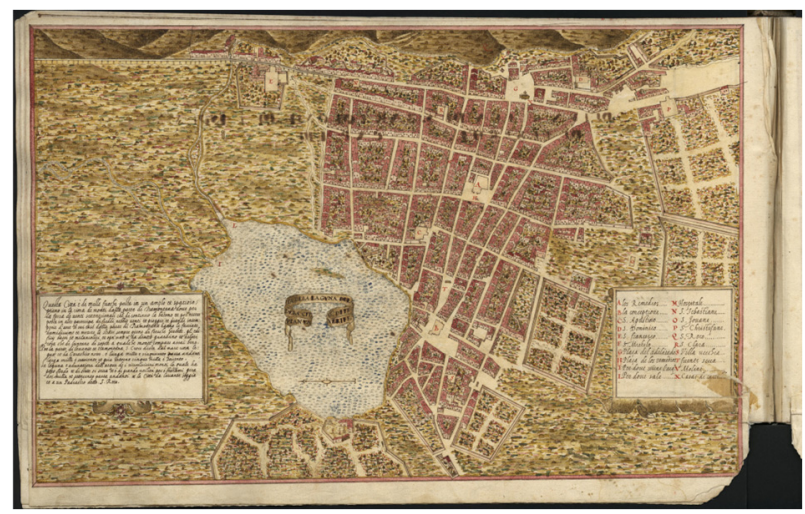

Figure 1: Torriani's map of La Laguna. (source: Library of the University of Coimbra).

The coexistence between the old houses of Mudejar tradition, the old convents, the eclectic architecture, and the new urban plans characterize the most contemporary stage. However, there have been no substantive changes in its urban layout since then, an issue that has been key to obtain on December 2, 1999, the title of World Heritage Site.

\subsection{Constructive features in the houses in La Laguna in the XVI century}

The style of construction that is imposed in the city is Mudejar, highlighting 5 functional types: armoury house, barn house, commercial house, low house or casa terrera and high house or casa sobradada (Navarro, 1999; Navarro, Perera, \& Pérez, 2018). Large extensions of lime masonry are used, combined with corners, facades and stone towers. In the facades, the carpentry is distributed in frames, windows and balconies. The houses are structured in three parts that occupy the plot, with the built-up area facing the street and with a facade parallel to it. Following the house, there is a yard and in the last section the garden for self-consumption. In the city of La Laguna, the houses conform to the casa-corral type, which refers to a house with a garden and space for raising animals, this part of the site was fenced and is what is called the corral. The documents in which el Adelantado registered the plot concessions of the island of Tenerife between conquerors and settlers at the end of the conquest (datas) refer to their use for both house and garden.

The plots are rectangular, sometimes squared, resulting from the perfect division of the land (Larraz, 2009). The front of the plot faced the street and is usually the main facade of the house. The sides were called bottoms and the occupancy ratios of the house with respect to the plot were usually: 1 to 1.5 or 1 to 2 . The plots were fully occupied, even by building a wall on its perimeter (Fig. 2). The construction system used is simple; the design of the Andalusian house-room is simplified, due to the shortage of construction craftsmen and the difficulty to obtain the materials.

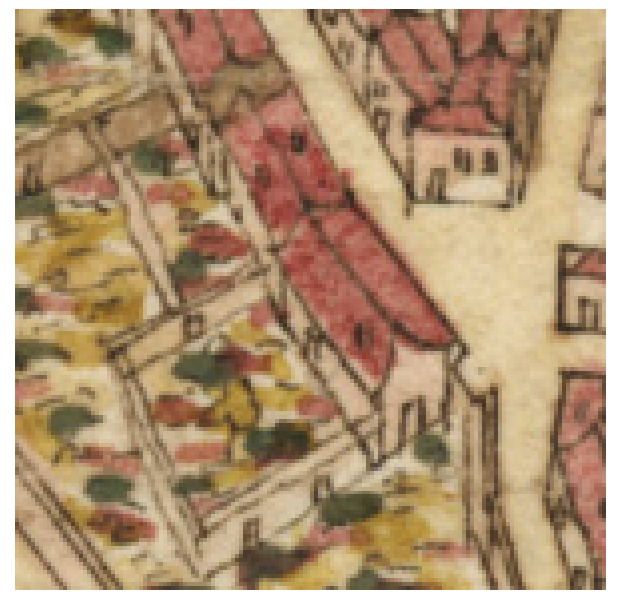

Figure 2: Houses with a yard and garden. Detail from Torriani's map of La Laguna.

In the city, houses had two types of roofs: straw or ceramic tiles (Larraz, 2009). Although the construction of thatched roofs was forbidden, it was common to find thatched houses, in which the roof was made of intertwined straw. These houses could be found of two types: adobe and straw and stone and straw. In rural areas, their structure is simpler, but in the city, they usually had the same dimensions and construction 
system as the tiled ones. They were usually of a quadrangular plant, the inner part was divided by means of partitions of adobe walls, dry stone or masonry walls. It was common for thatched houses to have a single room, but if they had more than one it was because of the existence of several terraced houses. The rooms were not connected to each other, in case several of them existed, the communication was made through the yard.

The second type of housing is tile houses; in these the construction systems are more complex. They are usually of two floors and compartments are made more frequently. Stone walls are used to build the house and the stonework is incorporated for the carved corners and the compartments.

The high houses (sobradada or sobrada) refer to those that have more than one floor (Navarro, 1999; Larraz, 2009). The staircase to access the second floor used to be attached to the outside. The first section corresponded to a stone staircase, which gives access to a wooden staircase that ends at the access door. In higher category houses, it can be found inside, starting either from the lobby or from the main room.

\subsection{Morphology of the sobrada house}

It has been chosen to reproduce a tiled sobrada house that was mainly present in the Lower Town, so below we detail the morphology and features of this type of housing that have been included in the 3D model.

The sobrada house usually had two floors: one at the street level and the sobrado floor over it (Navarro, 1999; Larraz, 2009). The sobrado floor was usually used as a barn with the intention of preserving crops from moisture. Due to the simplicity of the constructions, they did not usually have many compartments in the structure, so it was common for the rooms to have a window to the street and a door to the yard, acting as a connecting link between the rooms. Besides the yard, there was a garden with fruit trees, vineyards and crops. Some space was also reserved for animals.

The access to the house was made through the main door that lead to the living-dining room or main room and in opposite direction directly to the yard's access in the simplest houses. When housing extensions were built, the yard was the growth zone. The kitchen was usually set up as an extension in the yard, located in an area protected from the wind. In the kitchens a worktop or poyo made of stone and mud to the back is constructed, a fireplace or hogar is located in the upper part that in the humblest houses is formed with 3 rocks or teniques (Pérez, 1967). An earthen or ditch floor is common, and 3 tiles were placed in the form of a pyramid, that in conjunction with the open door facilitated the exit of the smoke. Inside or outside the kitchen was an oven. When the kitchen is on the sobrado floor, it had its own fireplace. Finally, a well could also be found in the yard to provide water to the house.

\section{Modelling the house}

A two-floor house is designed with open-source software for 3D modelling (Blender, 2020). A simplified model has been chosen to be used in a web browser but retaining the main characteristics of the house. The model takes into account features such as measurements, proportions, floors, distribution of rooms, materials, etc. described in studies on the type of housing of the $\mathrm{s}$. XVI in San Cristóbal de La Laguna. More complex architectural details are not considered due to the performance limitations on the platform chosen for display. The house is in the range for the measurements at the time for a casa sobrada (Larraz, 2009). The front, which faces the street, is about 14 meters and the back of the house is about 10 meters. The height of the houses is not found in the bibliography and has been estimated at 9.5 meters (Fig. 3).

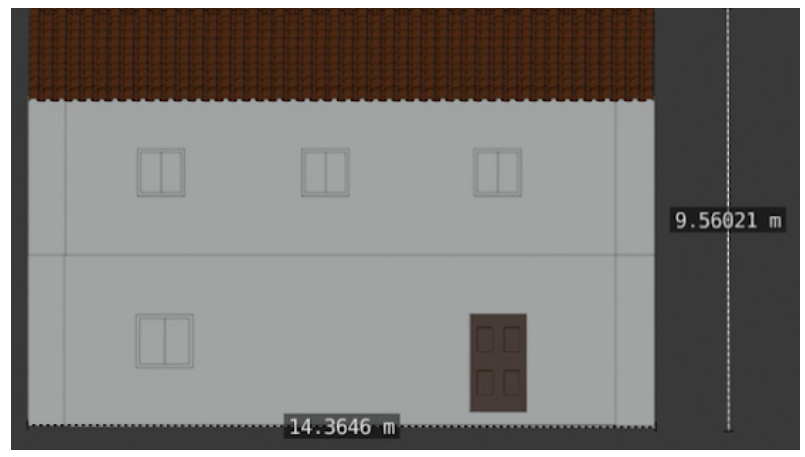

Figure 3: Front view of the house without textures.

The building site dimensions have been determined using a proportion house-plot around 1:3 (Larraz, 2009) as can be seen of Figure 4.

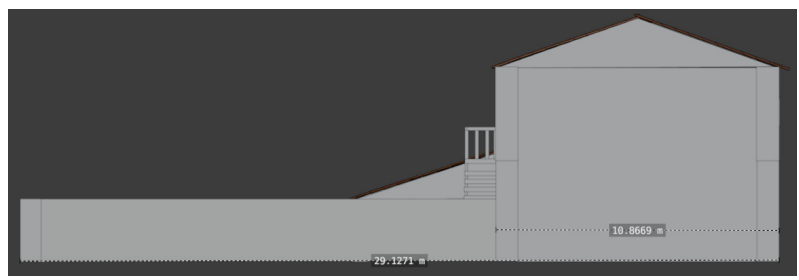

Figure 4: House and land measures.

The interior of the house is modelled by dividing the space into different rooms. On the ground floor, we find a living room and a bedroom, while the upper part is assigned the function of a barn. The living room was the space in which daily life took place; its furniture consists of some chairs and tables, cushions, stools or trunks. The access door to the house is located on the front and the access to the yard has been placed in front of it. A view of the living room is shown in Figure 5.

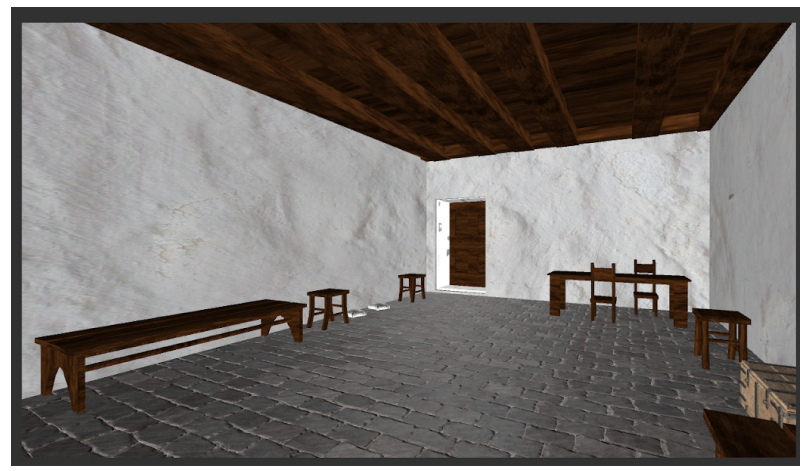

Figure 5: View of the living room. 
Room measures at the ground floor are both around 6 meters, and the barn measures 12 meters approximately, as they are shown in Figure 6.

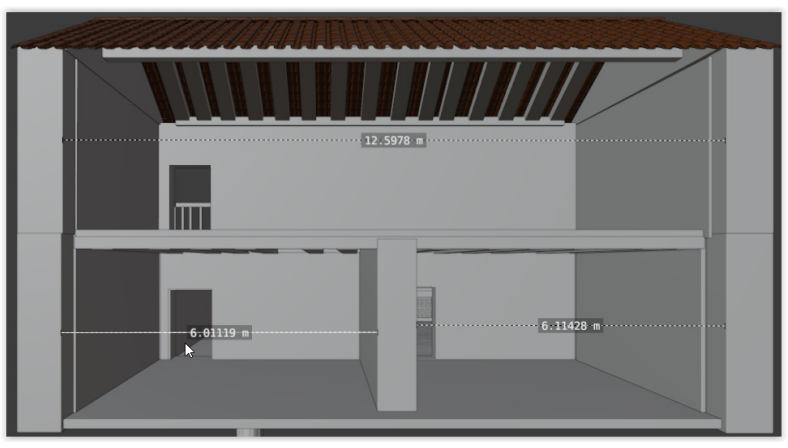

Figure 6: Room measures.

Simple furniture has been arranged in the bedroom room. It is composed of beds, trunks to store clothes and buckets. The room has a window to the street and also access through a door to the yard (Fig. 7).

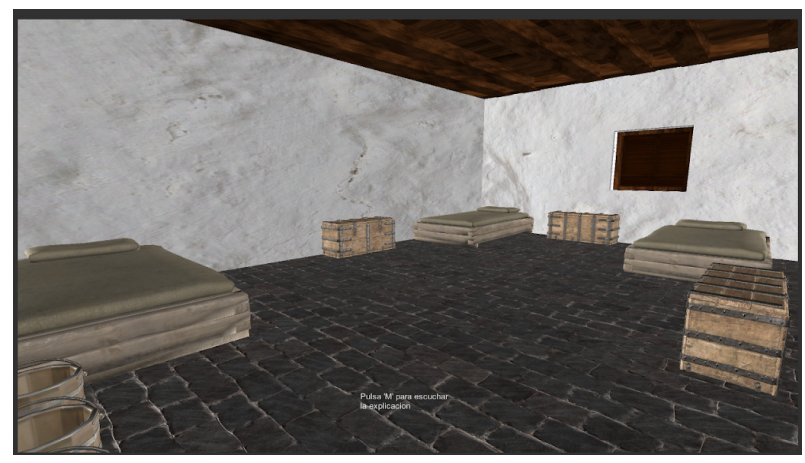

Figure 7: View of the bedroom.

The kitchen has been located in the yard, sharing a wall with the house. It has a stone kitchen top on where the fireplace is located. A cupboard has been added to keep the dishes along with a wooden table with some chairs (Fig. 8). Furthermore, an oven has been attached to the kitchen and some poultry pens have also been added to the model in the garden area (Fig. 9).

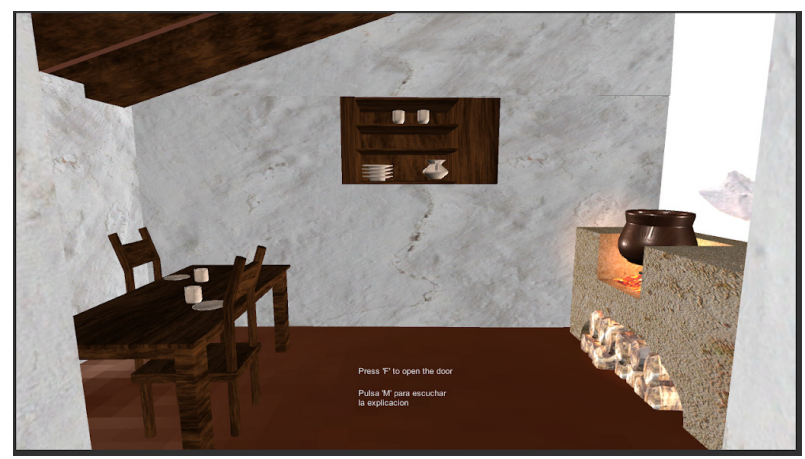

Figure 8: Inside view of the kitchen.

In the barn some sacks have been included along with some grain and wine casks. Some trunks to store household items such as blankets or farm equipment can also be seen (Fig. 10).

Both furniture and crops are assets that were acquired to develop the project. Six vineyard lines and wheat furrows were included in the garden. In the poultry pens some chickens and rabbits were included.

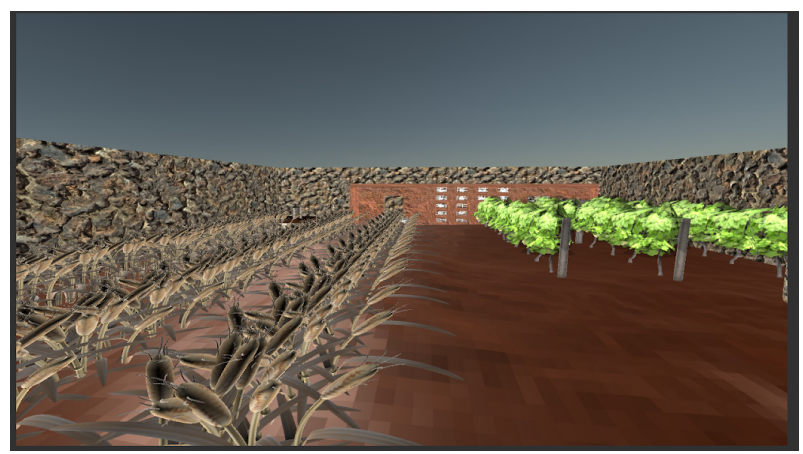

Figure 9: View of the garden and poultry pens.

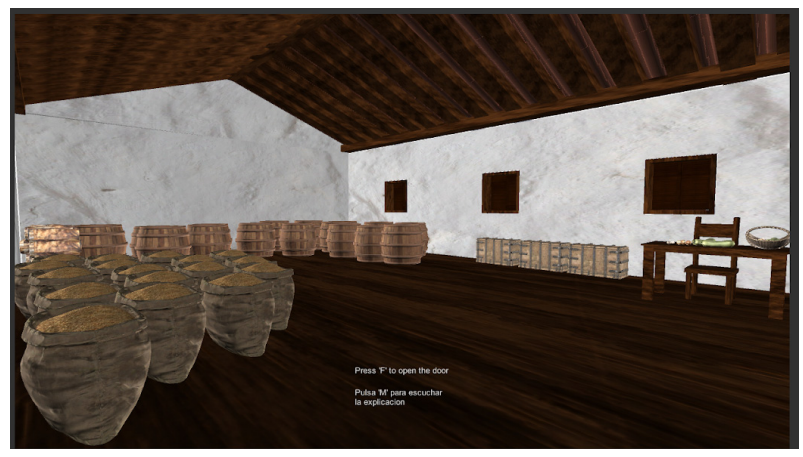

Figure 10: View of the barn.

\subsection{Materials}

In a 3D application, textures are essential for obtaining scenes with realism, for this reason they were carefully selected to obtain an aspect of the objects similar to those of the period. Most of the furniture models were acquired with their textures, however, to give them more verisimilitude, physically based rendering (PBR) textures for wood, stone and wool were obtained. They were applied to doors, walls and blankets respectively. Various materials were created for the exterior of the house. Images of stonework were chosen for the corners and for the interior, dry stone for the partitions, while for the ceiling, second floor and the doors of the house, pitchpine wood was used. Finally, brown tiles were used for the roof. The final result for Figure 6 is shown in Figure 11.

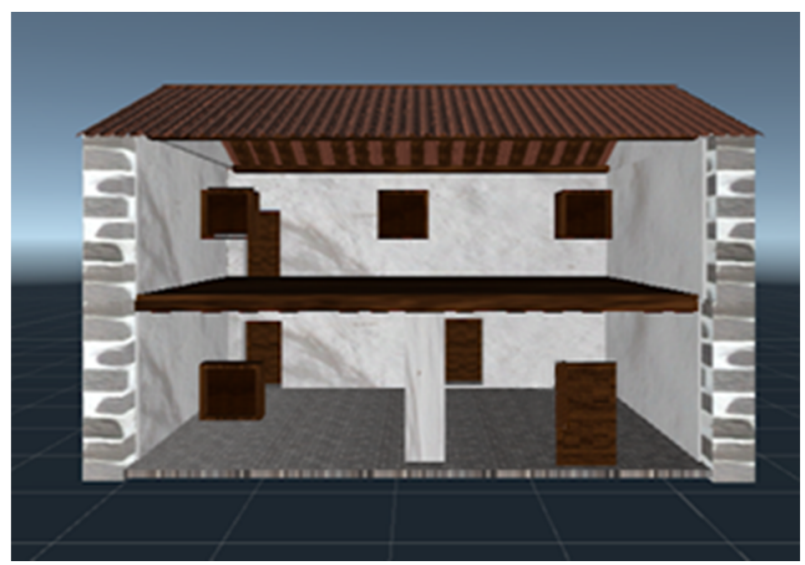

Figure 11: View of the house with textures. 


\section{Virtual Humans character design}

Advances in VR techniques now make it possible to recreate historical characters in great detail and bring them to life. By using people dressed in historical costumes, the recreation is more faithful, and it becomes an immersive experience of excellent quality. The recreation of historical characters allows the user to interact with them, see what they used to do and how they lived, and we can even join them in the daily life of the time. A fundamental part of the recreation of characters is the recreation of their clothing. In our case, it was necessary to study the type of clothing of the different social classes that lived together in the $16^{\text {th }}$ century in La Laguna. The type of clothing worn at that time is similar throughout Spain. To study how they dressed at that time, we have used as a basis the book entitled Geometria y traça perteneciente al oficio de sastres (De la Rocha, 1618). This book contains studies, patterns, types of fabric and very complete samples of all the clothing that a tailor must have known how to make at that time. However, this book is too complex to be used by someone without knowledge of historical tailoring. Fortunately, in the book El traje y los tipos sociales en el Quijote (Bernis, 2001) the information is collected in a more legible way and the patterns of the clothing are shown in a much clearer way. In addition, it includes drawings associated with the tailoring of that time (Fig. 12).

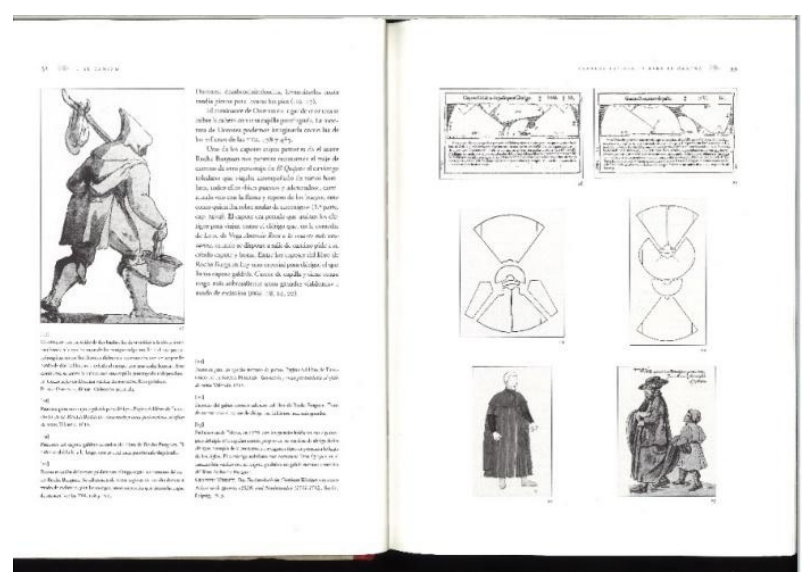

Figure 12: Book: El traje y los tipos sociales en el quijote (Bernis, 2001).

In addition, other sources were consulted such as $17^{\text {th }}$ century men's dress patterns 1600-1630 (Braun, Costigliolo, North, Thorton, \& Tiramani, 2016) and web resources where historical dress patterns are provided (Vogue Fabrics, 2020). For the other details of the clothing, we consulted pictorial works from the period in which a character with the studied clothing appears.

Several techniques can be used to create $3 D$ models of $16^{\text {th }}$-century people with the appropriate clothing. The first option is to model the clothes with generic programs such as Blender, 3D Studio Max, ZBrush, etc. However, the use of generic $3 D$ modelling programs makes it very complex to create all the clothing in addition to the corresponding animations (Liu, Zhang, \& Yuen, 2010). A second option is to use a specific program to model the characters clothing (Frâncu \& Moldoveanu, 2015). Finally, the last option is the $3 \mathrm{D}$ scanning of clothing recreations of the period. This technique offers a 3D model in a short time with enough detail; however a single
3D mesh is obtained and a complex post-processing step is necessary to divide the different pieces of clothing of the character, beside having to incorporate the animation.

In this work we have chosen the second option and we have used a specific program to create all clothing. The selected program is Marvelous Designer (CLO Virtual Fashion Inc, 2020) widely used in the fashion design industry as well as in entertainment. The program creates the clothing almost automatically from the drawing of a pattern (Spahiu, Shehi, \& Piperi, 2014). It works with already incorporated characters (avatars) although they can be edited and customized. The learning curve of this program is very fast and basic garments can be made in a short time without prior advanced knowledge of 3D modeling or sewing. It is also easy and fast to make variants of the clothing in shape, color and texture or to add details such as buttons, cuts, different lengths, etc. However, its use becomes more complicated with complex clothing when more details are incorporated. Marvelous Designer creates an automatic animation of the clothes when the character moves, since it incorporates into the cloth design the characteristics of the fabrics, such as weight, grammage, movement of clothes when walking, elasticity, etc.

The results of the program are shown below for simple clothes like a priest's suit (Fig. $13 \mathrm{a}$ and b) and a peasant girl's dress (Fig. $13 \mathrm{c}$ and d). These garments are composed of six pieces.

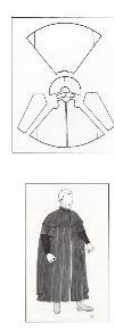

(a)

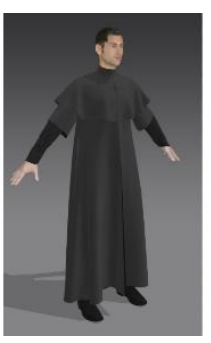

(b)

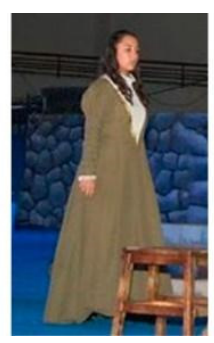

(c)

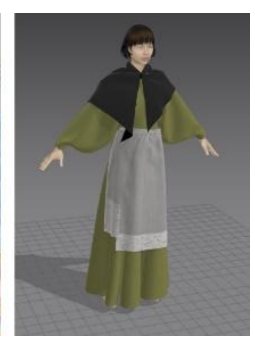

(d)
Figure 13: Results of the program Marvelous Designer: a) Dress patterns of a priest from the book (Bernis, 2001); b) Result; c) Study of the dress of a countrywoman (theater); d) Result.

The process taken for the creation of characters has been the following, first the pattern of the clothes is imported as a reference in the program (Fig. $14 \mathrm{a}$ ). This pattern is used to draw over the main pieces of clothing. Once the book patterns have been redrawn in one of the windows of the Marvelous Designer program (Fig. 14 b), the measurements are corrected and adjusted to the proportions of the avatar (3D model of the character without clothes). Then the different parts of the pattern are placed in the $3 D$ window in the right place above the avatar, the pieces are virtually sewn and finally adjusted using program options (Fig. $14 \mathrm{c}$ ).

For the dressing of the social strata of the nobility, an exhaustive study of the clothes to be designed is required (Fig. 15 a) because the clothing of the $16^{\text {th }}$ century is complex and the patterns are described with terms that are not commonly used today. When many details are added, the program needs more and more resources to animate the design. Likewise, once the design is exported to incorporate the figures into the VR application, it 
requires too many computer resources. This is why we have chosen to simplify the clothing as much as possible, avoiding the creation of details and non-essential extras. We have solved the colour changes in the fabric, the seams of different materials, buttons, etc. by drawing directly on the fabric. To do this, a flat image has been taken from the pattern once all the measurements and details have been adjusted. For this pattern, a texture image has been created using an editing program like Adobe Photoshop adding there all the details, embroideries, fabric changes, seams, etc. (Fig. 15 b). By adding the details with the texture as a drawing over the fabric, a result very similar to the original has been achieved (Fig. $15 \mathrm{c}$ ).

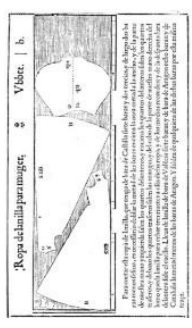

(a)

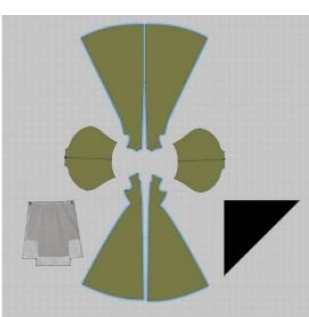

(b)

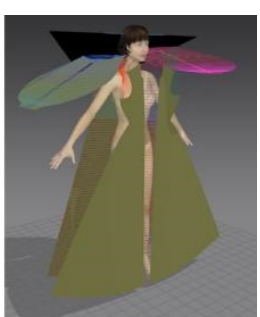

(c)
Figure 14: Process taken for the creation of characters: a) Detail of the pattern book reference image (Bernis, 2001); b) Pattern redrawn in Marvelous Designer; c) Placement in 3D space and virtual sewing.

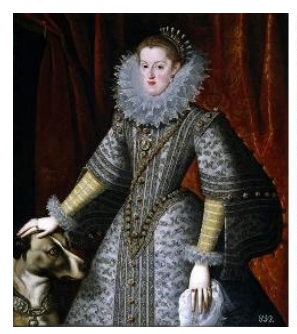

(a)

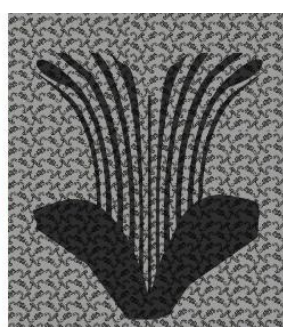

(b)

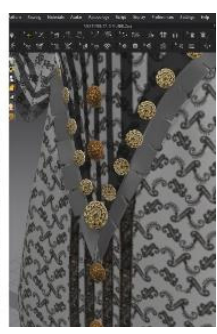

(c)
Figure 15: Study of the dress of the nobility a) Queen Marguerite of Austria, 1609, Author: Gonzalez, Bartholomew; b) One single texture to avoid many pieces of different fabrics; c) Result in Marvelous Designer.

For this type of complex clothing, the use of specific programs such as Marvelous Designer is a wise decision since these designs require modelling tools not present in generic programs such as Blender.

\section{Development of the interactive 3D application}

\subsection{Implementation}

An application has been implemented in (Unity Technologies, 2020) designed for VR devices that is currently in a web version, so the mechanics correspond to a first-person application. The user moves through the scene and decides which place to visit, starting the visit on the street facing the house. The visit has been designed similar to a museum visit with an audio guide. In this way when entering each room or accessing the yard the relevant characteristics recreated in each location are described. The mechanics implemented include the control of the user's movements for navigation through the house, the yard and the exterior street, as well as the automatic opening of doors when entering an area of influence.

\subsection{Integration of characters}

The human virtual characters are located static in the scene. They are able to reproduce the audios with fragments of the books of agreements of the Cabildo and also protocols of different notaries that serve as reinforcement to the explanations reproduced. Table 1 includes the texts reproduced by the characters, corresponding to notes in (Larraz, 2009) referred to collections of Agreements of the Cabildo and Protocolos Notariales in the Fontes Rerum Canarium collection of the Instituto de Estudios Canarios, In this case, scripts have also been implemented to facilitate the playback of the audio when the user enters in the character's action area.

A crucial aspect to give realism to the characters is the physical simulation of the costumes. Marvelous Designer has a powerful physics simulation engine that responds to clothing behaviour. The properties of the fabrics are configurable, there are some types already preestablished like wool, cotton, and silk or define our own fabrics. Although the simulation is generated with Marvelous Designer software, it is necessary to export the model in a format that supports the transfer of this information to Unity. By using Blender as an intermediate step this purpose can be achieved through the Alembic format. This open format condenses information from animated scenes into a set of pre-calculated results on geometry. This process is analogous to texture baking. Today it has become a common format for transferring complex animated models between development teams.

Since the VR application will be accessed through the web the generated meshes must be optimized, for which Blender is used again. In the process of optimizing meshes, the geometric elements of the garment mesh are ordered, since mesh aberrations may appear from an automatic export and very complex meshes may be obtained. The optimized model in Alembic format can be integrated into a Unity3D scene using the AlembicForUnity package. Some characters in the living room and the kitchen are shown in Figures 16 and 17 respectively.

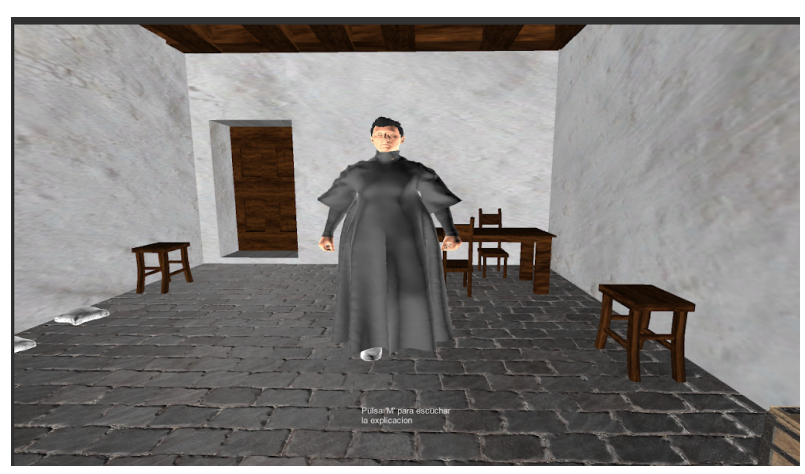

Figure 16: Priest character in the room.

\subsection{Optimization}

The application has been optimized for smooth execution on the necessary hardware resources. For this purpose, the ogg format has been used for the audios since it 
preserves the sound quality and has a lower weight than others such as mp3 or m4a. This decision made a great improvement in the time to load the application. Moreover, the application uses the Unity3D Static Batching mode that reduces the call draws of objects of any size. This option is best for geometric objects that share material and do not move. Given the characteristics of the scene, both requirements are met in the housing model. Finally, in the WebGL version the options for the player have been configured in background execution, so that if the browser's containing window is not the main window, the application will continue to run even if it loses focus.

Table 1: Ancient texts from the $16^{\text {th }}$ century used as audios.

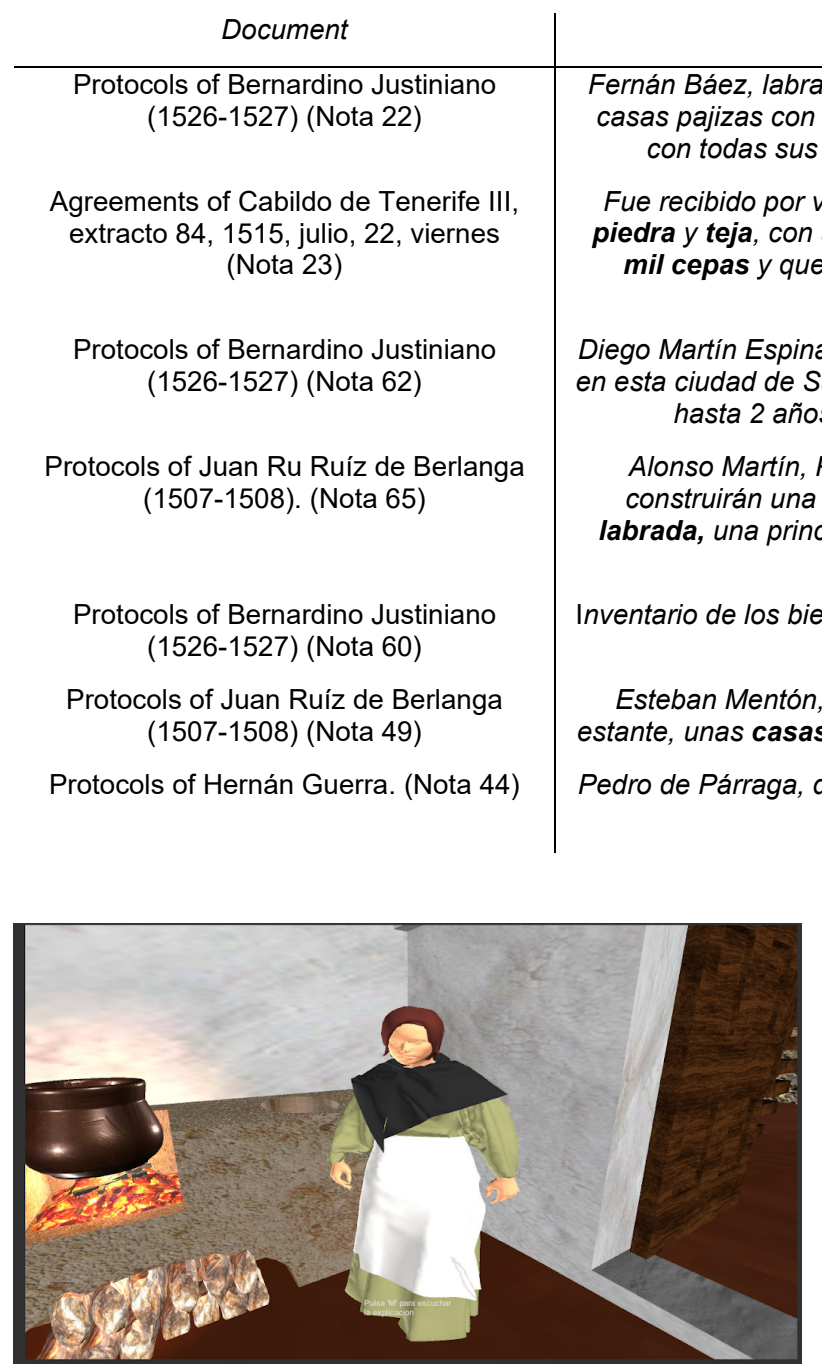

Figure 17: Cook character next to the kitchen stove.

\section{Conclusions}

Nowadays there is a large amount of historical documentation of the Canary Islands including documents that provide information about what the houses and customs of society were like in the $16^{\text {th }}$ century. A tool of increasing importance for the dissemination and preservation of history and cultural heritage are reconstructions and virtual recreations in 3D. This paper presents a case of use of these tools for the dissemination of the city's heritage.

A 3D environment with a high level of detail has been designed for a sobrada house in San Cristóbal de La Laguna in the $16^{\text {th }}$ century along with its yard and garden. Human virtual characters were incorporated with clothing of that age. They were designed using the Marvelous Designer program. The use of textures to imitate details such as fabric changes, stitching, buttons, etc. has made
Text-Audio

venden a Sancho Caballero mercader, vecino, unas
y su mujer, venden a Sancho Caballero mercader, vecino, unas s puertas a la calle real, con sus corrales, horno, medio pozo y Antonio Font con tal que haga una casa de sesenta pies, de
sobrado y que la edifique nueva y que haga una viña de cinco en cinco años y que en dos años la plante y fabrique. arrienda a Juan Descano, un sobrado de las casas de su morada
Cristóbal. Lo arrienda desde el día de San Juan de junio venidero umplidos, cada año por el precio de 1 cahíz de buen trigo.

Cristóbal y Juan Álvarez, portugueses, pedreros y albañiles a Fernando Llerena, que llevará tres portadas de cantería escalera para entrar en la cámara.
escalle, otra en la sala y

Marcos Franco, mercader difunto: primeramente en un sobrado

un montón de trigo de unas 150 fanegas.

serrador, portugués, con su corral y pozo, situadas en la calle que va a San Francisco.

da a renta a Fernán Alonso Galíndez y a Antón Galíndez unas casas con corral y un horno que tiene en esta villa.

it possible to create light models. In addition, by changing the $2 \mathrm{D}$ image of the fabric texture, several variants of the garment are achieved without having to change the entire 3D model.

The 3D environment and the characters have been integrated in a VR application developed with Unity where the user has absolute control of movement and can receive historical information about the house both visually and audibly. Various mechanics have also been applied so that the user can interact with the application without tools other than the keyboard of their computer.

The application has been developed for a web platform, and certain optimizations have been considered to make the performance of the application as smooth as possible. The application has been hosted on a website where Unity developers upload their projects.

An application like this contributes to the dissemination of the cultural and architectural heritage of the city of San Cristobal de La Laguna. It can be very instructive not only for visitors who want to know more about the history of the city but also to be used in training activities in schools, so that children can learn and understand in a more visual way how life was at that time using an attractive media support for the historic content.

\section{Acknowledgements}

This work was supported by the Fundación CajaCanarias and Fundación Bancaria La Caixa under Patrimonio Cultural en Canarias: del legado aborigen a la nueva sociedad canaria. 


\section{References}

Abreu Galindo, J. [1632] (1977). Historia de la conquista de las siete islas de Canaria. Introducción y notas de A. Cioranescu. Goya Ediciones, Santa Cruz de Tenerife.

Aznar Vallejo, E. (2008). La Época Fundacional y su influjo en el patrimonio histórico de san Cristóbal de La Laguna. Anuario de Estudios Atlánticos, 54-1, Madrid-Las Palmas, España, pp. 169-205.

Bernis, C. (2001). El traje y los tipos sociales en el Quijote. Madrid: Ediciones El Viso.

Bekele, M. K., Pierdicca, R., Frontoni, E., Malinverni, E. S., \& Gain, J. (2018). A survey of augmented, virtual, and mixed reality for cultural heritage. Journal on Computing and Cultural Heritage (JOCCH), 11(2), 1-36. https://doi.org/10.1145/3145534

Blender Foundation. (2018). Blender - a 3D modelling and rendering package. Stichting Blender Foundation, Amsterdam. Retrieved September 28, 2020, from http://www.blender.org

Bostanci, E., Kanwal, N., \& Clark, A. F. (2015). Augmented reality applications for cultural heritage using Kinect. Humancentric Computing and Information Sciences, 5(1), 1-18. https://doi.org/10.1186/s13673-015-0040-3

Braun, M., Costigliolo, L., North, S., Thorton, C., \& Tiramani, J. (2016). 17 th-Century men's dress patterns 1600-1630. London: Victoria \& Albert Museum Thames \& Hudson.

Carrozzino, M., \& Bergamasco, M. (2010). Beyond virtual museums: Experiencing immersive virtual reality in real museums. Journal of Cultural Heritage, 11(4), 452-458. https://doi.org/10.1016/j.culher.2010.04.001

Cioranescu, A., 1965. La Laguna: Guía Histórica y Monumental. Ayuntamiento de San Cristobal de la Laguna.

De la Rocha Burguen, F. (1618). Geometria y traça perteneciente al oficio de sastres. Valencia.

Frâncu, M., \& Moldoveanu, F. (2015). Virtual try on systems for clothes: Issues and solutions. UPB Sci. Bull., 77(4), 3144.

Larraz Mora, A. (2009). A vista de oficiales y a su contento. Tipología sistemas constructivos de la vivienda de La Laguna y Tenerife a raíz de la conquista. Ed. Instituto de Estudios Canarios, año 2009. ISBN: 978-84-88366-68-9.

Liu, Y. J., Zhang, D. L., \& Yuen, M. M. (2010). A survey on CAD methods in 3D garment design. Computers in Industry, 61(6), 576-593. https://doi.org/10.1016/j.compind.2010.03.007

Machidon, O., Duguleană, M., \& Carrozzino, M. (2018). Virtual humans in cultural heritage ICT applications: A review. Journal of Cultural Heritage, 33, 249-260. https://doi.org/10.1016/j.culher.2018.01.007

CLO Virtual Fashion Inc. (2020). Marvelous Designer. Retrieved September 28, 2020, from https://www.marvelousdesigner.com/

Navarro Segura, M. I. (1999). La Laguna 1500: la ciudad-república. Una utopía insular según las leyes de Platón. La Laguna (Spain): Excmo. Ayuntamiento de San Cristóbal de La Laguna.

Navarro Segura, M., Perera, F., \& Pérez, D. (2018). Arquitectura en La Laguna: El concepto vernáculo. Criterios de protección y el papel del dibujo. Revista de Historia Canaria. 155-176.

Pérez Vidal, J. (1967). La vivienda canaria. Datos para su estudio. Anuario de Estudios Atlánticos, 12, 41-113.

Spahiu, T., Shehi, E., \& Piperi, E. (2014). Advanced CAD/CAM systems for garment design and simulation. $6^{\text {th }}$ International conference of textile, (págs. 1-6). Tirana, Albania.

Unity Technologies. (2020). Unity Real-Time Development Platform | 3D, 2D VR \& AR Engine. Retrieved September 28, 2020, from https://www.unity.com/

Vincent, M., DeFanti, T., Schulze, J., Kuester, F., \& Levy, T. (2013). Stereo panorama photography in archaeology: Bringing the past into the present through CAVEcams and immersive virtual environments. In 2013 Digital Heritage International Congress (DigitalHeritage), $\quad 1, \quad$ pp. $455-455 . \quad$ IEEE. https://doi.org/10.1109/DigitalHeritage.2013.6743783

Vogue Fabrics. (2020). Reconstructing History Pattern \#RH206 - Men's 1570-1600 Breeches or Trunkhose. Retrieved September 28, 2020, from https://www.voguefabricsstore.com/reconstructing-history-pattern-men-s-1570-1600breeches-or-trunkhose.html 